\title{
Produksi Olahan Bunga Rosella (Hibiscus Sabdariffa) di Desa Balongbendo Kabupaten Sidoarjo
}

\author{
${ }^{1 *}$ Martina Kurnia Rohmah, ${ }^{2}$ Yani Ambari, ${ }^{3}$ Khurin In Wahyuni \\ STIKES Rumah Sakit Anwar Medika; Jalan Semawut Kabupaten Sidoarjo \\ "Corresponding author: martina.kurniarohmah@gmail.com
}

\begin{abstract}
Abstrak
Keberadaan Rosella belum dimanfaatkan secara optimal padahal tanaman ini memiliki manfaat yang sangat luas dalam bidang pangan dan kesehatan melalui berbagai produk olahan (diversifikasi) karena minimnya pengetahuan dan ketrampilan masyarakat khususny dalam hal pengolahan. Tujuan program ini adalah memberikan pengetahuan, bimbingan, serta pendampingan dalam memanfaatkan bunga rosella menjadi berbagai produk olahan sehingga memiliki nilai ekonomis guna meningkatkan kesejahteraan masyarakat Desa Balongbendo. Metode pelaksanaan yang dilakukan dalam program ini adalah penyuluhan, penanaman tanaman Rosella, pelatihan pembuatan produk olahan bunga rosella, pelatihan pengemasan dan pemasaran produk bunga rosella, serta pendampingan pada pameran produk olahan di Kabupaten Sidoarjo. Hasil dari kegiatan ini adalah: (1) Meningkatnya pengetahuan mitra tentang manfaat, budidaya tanaman, dan diversifikasi produk olahan Rosella (2) Meningkatnya keterampilan mitra dalam mengolah bunga Rosella dengan berbagai produk, (3) Terciptanya produk-produk olahan bunga rosella yang telah dipasarkan dalam bentuk Teh Rosella, Sirup Rosella dan Es Krim Rosella (4) Meningkatnya daya saing msyarakat Desa Balongbendo se-kebupaten Sidoarjo.
\end{abstract}

Kata kunci-Produk Rosella, Teh Rosella, Sirup Rosella, Es Krim Rosella

\begin{abstract}
The existence of Rosella has not been optimally utilized even though this plant has very broad benefits in the field of food and health through a variety of processed products (diversification) because of the lack of knowledge and skills of the community specifically in terms of processing. The purpose of this program is to provide knowledge, guidance, and assistance in utilizing roselle flowers into various processed products so that they have economic value in order to improve the welfare of the people of Balongbendo Village. The method of implementation carried out in this program are: counseling, planting Rosella plants, training in making processed Rosella flower products, training in packaging and marketing of rosella flower products, and assisting at the exhibition of processed products in Sidoarjo Regency. The results of this activity are: (1) Increased knowledge of partners about the benefits, cultivation of plants, and diversification of processed Rosella products (2) Increased partner's skills in processing Rosella flowers with various products, (3) Creation of processed rosella flower products that have been marketed in the form of Rosella Tea, Rosella Syrup and Rosella Ice Cream (4) Increasing the competitiveness of Balongbendo Villages throughout the Sidoarjo Regency.
\end{abstract}

Keywords-Rosella Products, Rosella Tea, Rosella Syrup, Rosella Ice Cream

\section{PENDAHULUAN}

$\mathrm{T}$ anaman Rosella (Hibiscus sabdariffa) merupakan salah satu jenis tanaman perdu yang memiliki potensi sebagai sumber bahan pangan fungsional dan memiliki banyak manfaat di bidang kesehatan. Baik akar, batang, daun dan bunga tanaman ini memiliki kandungan antioksidan seperti Vitamin $\mathrm{C}$ dan Antosianin yang tinggi terutama pada bagian bunga
(Nurnasari \& Khuluq, 2018). Berdasarkan penelitian yang telah ada, Bunga Rosella memiliki manfaat di bidang kesehatan diantaranya sebagai antibakteri (Mungole \& Chaturvedi, 2011), antiinflamasi (Badan Pengawas Obat dan Makanan Republik Indonesia, 2010), antidiabetes (Mardiah dkk, 2015), dan antihipertensi (Kusumastuti, 2014).

Desa Balongbendo Kecamatan Balongbendo Kabupaten Sidoarjo merupakan salah satu desa yang 


\section{Rohmah dkk. / Jurnal Karinov Vol. 2 No. 3 (2019) 167-170}

berada di dataran rendah dengan iklim panas di wilayah Sidoarjo barat. Di sekitar pekarangan rumah dan beberapa lahan kosong ditumbuhi tanaman Rosella yang berlum dimanfaatkan secara optimal. Padahal tanaman Rosella terutama bagian bunganya memiliki potensi khususnya dalam bidang pangan dan kesehatan. Permasalahan yang dihadapi mitra saat ini adalah kurang aktifnya masyarakat Desa Balongbendo dalam memanfaatkan potensi alam sekitar sehingga tanaman Rosella ini tidak dimanfaatkan dengan baik. Padahal jika masyarakat Desa Balongbendo mau mengolahnya akan menjadi sumber pendapatan tambahan terutama bagi ibu rumah tangga. Masyarakat Desa Balongbendo belum memiliki pengetahuan yang cukup terkait dengan manfaat bunga Rosella dalam bidang kesehatan, budidaya dan bentuk diversifikasi produk olahan yang dapat dibuat, serta tidak memiliki keterampilan yang baik dalam hal pengolahan bunga Rosella.

Pemberdayaan masyarakat merupakan salah satu pendekatan pembangunan dalam proses penguatan ekonomi untuk meningkatkan kesejahteraan hidup masyarakat terutama masyarakat desa. Pemberdayaan ekonomi masyarakat pedesan dalam bentuk pengabdian kepada masyarakat yang menitikberatkan pada pelatihan dan pembinaan kelompok masyarakat terutama ibu rumah tangga. Kegiatan pengabdian kepada masyarakat ini bertujuan untuk memberikan pengetahuan, bimbingan, serta pendampingan dalam pemanfaatan bunga Rosella menjadi berbagai produk sehingga memiliki nilai ekonomis guna meningkatkan kesejahteraan Desa Balongbendo terutama Ibu-Ibu rumah tangga. Adapun target kegiatan ini antara lain: keterlibatan aktif masyarakat, peningkatan pengetahuan masyarakat, peningkatan ketrampilan pengolahan bunga Rosella, adanya produk bunga Rosella yang siap dipasarkan, serta meningkatnya daya saing masyarakat Desa Balongbendo.

\section{METODE}

Kegiatan ini dilakukan di Desa Balongbendo Kecamatan Balongbendo Kabupaten Sidoarjo. Metode pelaksanaannya terdiri dari penyuluhan, pelatihan, dan pendampingan. Tahapan yang dilakukan pada kegiatan ini antara lain: tahap persiapan, survei, penyuluhan, budidaya, pembuatan produk olahan, serta pelaksanaan pameran dan penjualan. Tahap persiapan dilakukan dengan melakukan rapat koordinasi dengan perangkat Desa
Balongbendo terkait dengan kegiatan pengabdian masyarakat yang akan diadakan serta persiapan teknis dan pembagian tugas tim dosen dengan mahasiswa. Tahap survei dilakukan dengan melihat lokasi dan keberadaan tanaman Rosella di Desa Balongbendo, kondisi tanah, dan lingkungan sekitar. Tahap penyuluhan dilakukan untuk memberikan pengetahuan terkait dengan manfaat, cara budidaya, serta cara-cara pengolahan bunga Rosella yang dilakukan di rumah warga dengan melibatkan perangkat desa, Ibu PKK, kader lingkungan, karang taruna, dan juga ibu rumah tangga. Tahap budidaya dilakukan untuk mempersiapkan bahan baku produk selain dari tanaman yang sudah ada. Tahap pengolahan produk merupakan tahap produksi yang dilakukan di rumah-rumah warga yang terbagi dalam kelompok-kelompok usaha. Tahap pameran dan penjualan merupakan tahap untuk memperkenalkan produk hasil olahan bunga Rosella serta penjualan produk olahan.

\section{HASIL DAN PEMBAHASAN}

Kegiatan pengabdian kepada masyarakat dilaksanakan oleh tim yang terdiri dari 2 orang dosen dan 40 orang mahasiswa. Kegiatan ini telah berhasil melibatkan 60 orang dari sejumlah lapisan masyarakat terutama ibu rumah tangga dengan data pada Gambar 1.

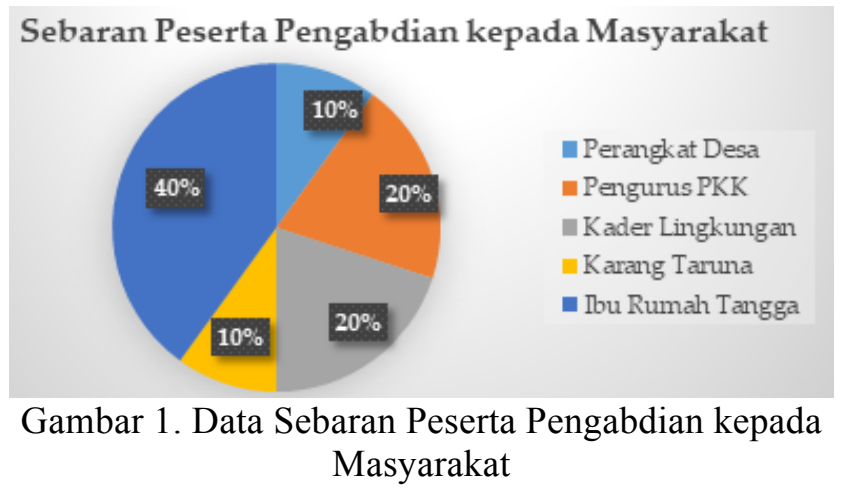

Masyarakat yang terlibat dalam kegiatan pengabdian kepada masyarakat ini adalah perangkat desa $(10 \%)$, pengurus PKK $(20 \%)$, kader lingkungan (20\%), karang taruna (10\%), dan ibu rumah tangga (40\%). Kegiatan penyuluhan yang telah dilakukan diberikan dalam wujud penyuluhan terkait karakteristik tanaman Rosella, manfaat tanaman Rosella bagi kesehatan, cara budidaya, serta diversifikasi produk olahan Rosella ditunjukkan pada Gambar 2. 


\section{Rohmah dkk. / Jurnal Karinov Vol. 2 No. 3 (2019) 167-170}

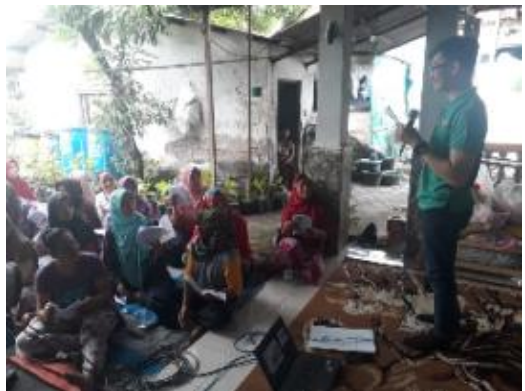

Gambar 2. Dokumentasi Kegiatan Penyuluhan Karakteristik dan Manfaat Rosella, Budidaya Rosella, dan Cara-Cara Pengolahan Rosella

Dalam penyuluhan ini, kami melakukan evaluasi terkait dengan pengetahuan masyarakat dengan dilakukannya pre dan post-test. Adapun hasil pre dan post-test ditunjukkan dengan grafik pada Gambar 3.

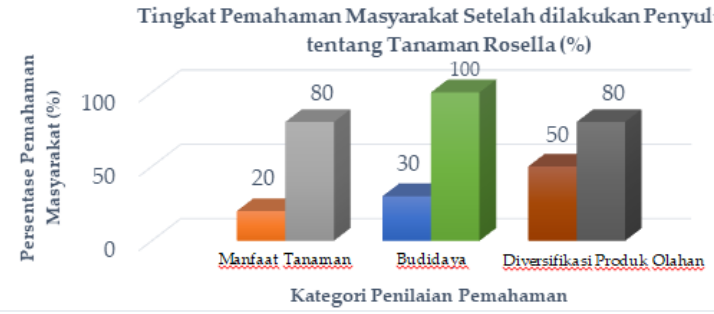

Gambar 3. Grafik Peningkatan Pemahaman Masyarakat Setelah dilakukan Penyuluhan tentang Tanaman Rosella

Setelah dilakukan penyuluhan, kami melakukan penanaman dan budidaya tanaman Rosella untuk menyediakan bahan baku selain yang telah ada. Kegiatan penanaman dan penyediaan bibit terlihat pada Gambar 4.
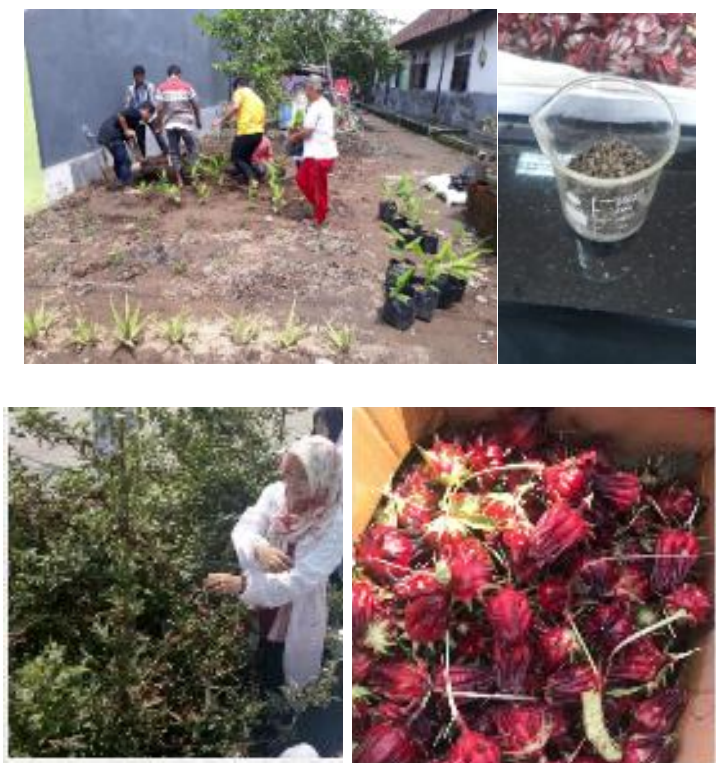

Gambar 4. Kegiatan Penanaman, Penyiapan Bibit, dan Panen Bunga Rosella
Selain kegiatan penyuluhan dan penanaman tanaman Rosella, kegiatan pelatihan pembuatan produk unggalan menjadi kegiatan paling penting dalam pemberdayaan masyarakat ini. Bunga Rosella diolah dalam bentuk teh seduhan, sirup, dan juga es krim Rosella ditunjukkan Gambar 5.
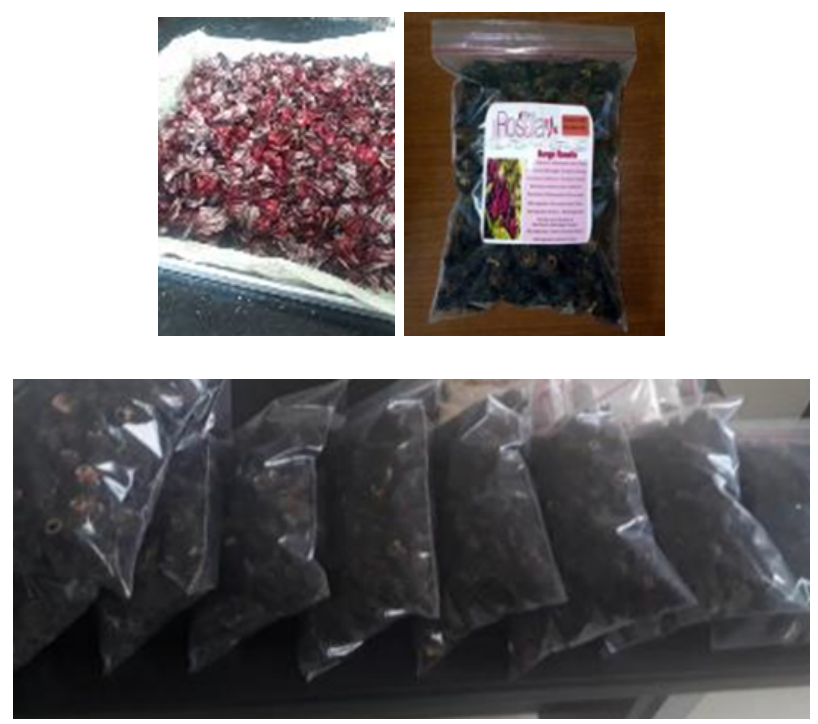

Gambar 5. Kegiatan Pengolahan Bunga Rosella menjadi Teh Seduhan
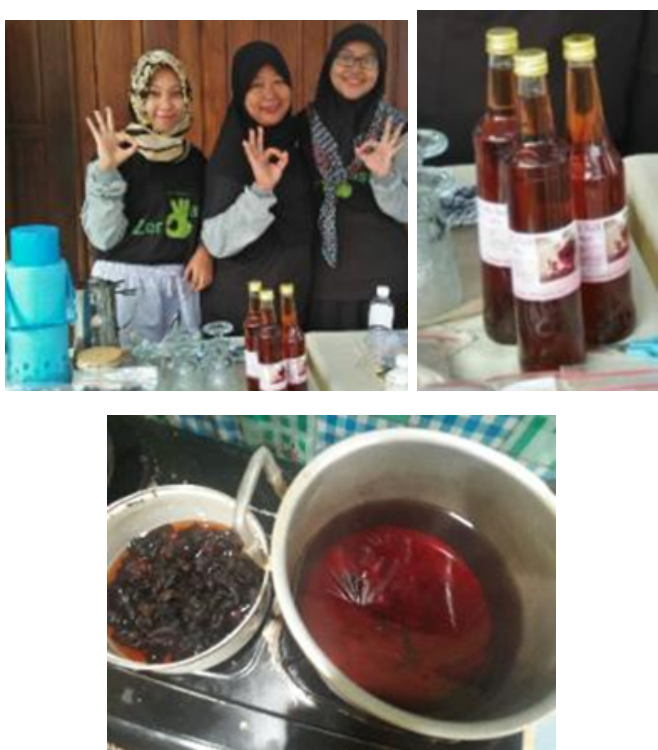

Gambar 6. Kegiatan Pengolahan Bunga Rosella menjadi Sirup
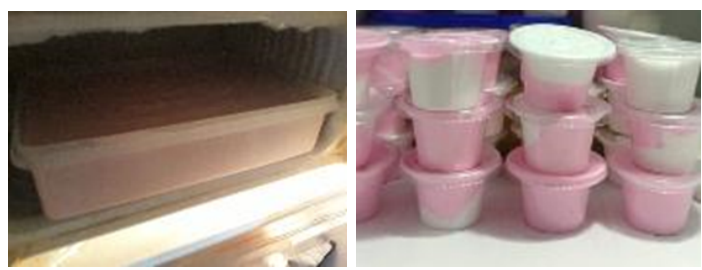

Gambar 7. Kegiatan Pengolahan Bunga Rosella menjadi Sirup 


\section{Rohmah dkk. / Jurnal Karinov Vol. 2 No. 3 (2019) 167-170}

Produk olahan bunga Rosella diperkenalkan melalui kegiatan lomba dan bazar Desa kemudian dipasarkan pada masyarakat sekitar (lokal) yang ditunjukkan pada Gambar 8.
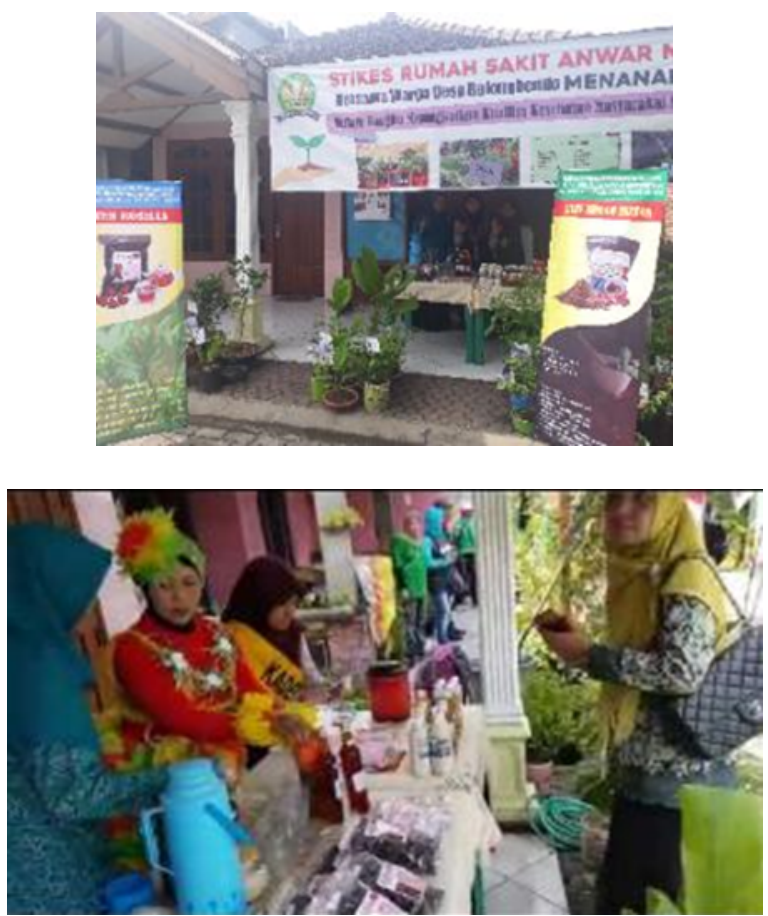

Gambar 8. Kegiatan Pameran Produk Olahan Bunga Rosella Desa Balongbendo

Target-target kegiatan pengabdian masyarakat ini telah dipenuhi termasuk juga peningkatan daya saing masyarakat Desa Balongbendo yaitu melalui prestasi masuk dalam 4 besar lomba olahan toga sekabupaten Sidoarjo dari Kelompok Asman Rosella PKM Desa Balongbendo Kecamatan Balongbendo Kabupaten Sidoarjo. Mengingat kegiatan pengabdian ini masih berupa kegiatan awal, maka kedepan perlu dilakukan pengembangan-pengembangan melalui pemberdayaan masyarakat desa Balongbendo. Hal yang perlu dikembangkan dari kegiatan pengabdian kepada masyarakat untuk berikutnya adalah peningkatan ragam produk olahan toga tidak hanya berupa minuman kesehatan namun juga produk makanan lainnya dan produk kecantikan berbahan dasar bunga Rosella seperti masker dan pilling mengingat tingginya kandungan antioksidan bunga Rosella. Selain pengembangan variasi produk olahan, perlu dilakukan juga pengembangan teknologi kemasan yang lebih aman, praktis dan tahan lama, pengurusan ijin produksi serta berbagai teknik pemasaran produk.

\section{SIMPULAN}

Melalui kegiatan pengabdian ini, masyarakat Desa Balongbendo telah (1) memahami manfaat budidaya tanaman, dan diversifikasi pengolahan produk olahan bunga Rosella terutama dalam bidang pangan dan kesehatan, (2) Meningkatnya keterampilan mitra dalam mengolah bunga Rosella dengan berbagai produk, (3) Terciptanya produkproduk olahan bunga rosella yang telah dipasarkan, dan meningkatnya daya saing masyarakat.

\section{UCAPAN TERIMAKASIH}

Ucapan terima kasih disampaikan kepada seluruh pihak-pihak terkait diantaranya Perangkat Desa Balongbendo dan Masyarakat selaku mitra, STIKES Rumah Sakit Anwar Medika selaku institusi yang mendanai kegiatan ini, serta mahasiswa yang turut aktif dalam mensukseskan kegiatan pengabdian kepada masyarakat ini.

\section{DAFTAR RUJUKAN}

Badan Pengawas Obat dan Makanan Republik Indonesia. (2010). Serial Data Ilmia Terkini Tumbuhan Obat: Rosella.

Kusumastuti, I. R. (2014). Roselle (Hibiscus Sabdariffa Linn) Effects On Lowering Blood Pressure As a Treatment For Hypertension. Jurnal Mayority, 3(7), 70-74.

Mardiah, Zakaria, F. R., Prangdimurti, E., \& Damanik, R. (2015). Anti-inflammatory of Purple Roselle Extract in Diabetic Rats Induced by Streptozotocin. Procedia Food Science, 3, 182-189. https://doi.org/10.1016/j.profoo.2015.01.020

Mungole, A., \& Chaturvedi, A. (2011). Hibiscus sabdariffa L a rich source of secondary metabolites. International Journal of Pharmaceutical Sciences Review and Research, 6(1), 83-87.

Nurnasari, E., \& Khuluq, A. D. (2018). Potensi Diversifikasi Rosela Herbal (Hibiscus sabdariffa L.) untuk Pangan dan Kesehatan. Buletin Tanaman Tembakau, Serat \& Minyak Industri, 9(2),82. 